Supporting Information for

\title{
Electrostatic-Driven Lamination and Untwisting of $\beta$-Sheet Assemblies
}

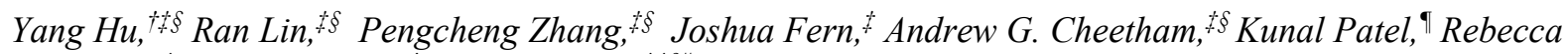
Schulman, ${ }^{*}$ Chengyou Kan, ${ }^{+}$Honggang Cui ${ }^{*}{ }^{*}{ }^{\prime} \#$

$\dagger$ Department of Chemical Engineering, Tsinghua University, Beijing, 100084, China, $\ddagger$ Department of Chemical and Biomolecular Engineering, and §Institute for NanoBiotechnology (INBT), Johns Hopkins University, Baltimore, Maryland 21218, United States, 9 Department of Biomedical Engineering, Johns Hopkins University, Baltimore, Maryland 21218, United States, \#Department of Oncology and Sidney Kimmel Comprehensive Cancer Center, Johns Hopkins University School of Medicine, Baltimore, Maryland 21205, United States.

\section{Contents}

S1 Molecular characterization of the studied peptides...................................................................... 2

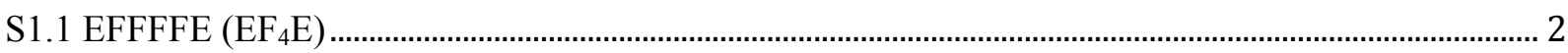

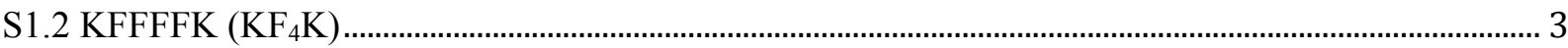

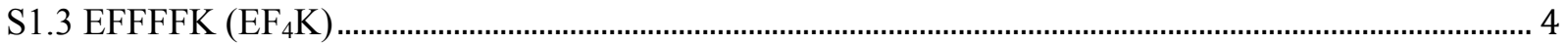

S1.4 EIIIIE (EI

S2 Characterization of the self-assembled nanostructures ................................................................. 6

S2.1 Height measurement of $\mathrm{EF}_{4} \mathrm{E}$ twisted ribbons by AFM ..................................................................... 6

S2.2 TEM images of self-assembled nanostructures of $\mathrm{EF}_{4} \mathrm{E}$.................................................................. 6

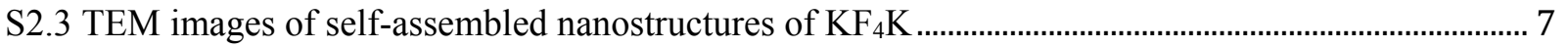

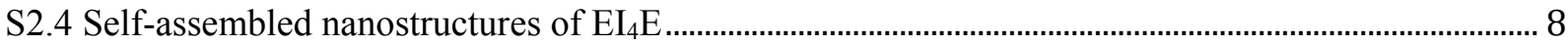

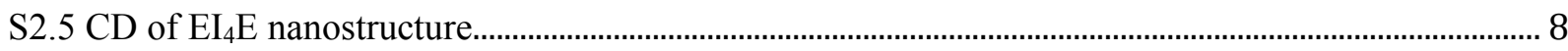

S2.6 Co-assembly of $\mathrm{EF}_{4} \mathrm{E}$ and $\mathrm{KF}_{4} \mathrm{~K}$ at different concentrations in water ...............................................

S2.7 Morphological transformation of $\mathrm{EF}_{4} \mathrm{E}$ and $\mathrm{KF}_{4} \mathrm{~K}$ mixture........................................................... 9

S2.8 Height measurement of $\mathrm{EF}_{4} \mathrm{~K}$ belts by AFM .....................................................................................10

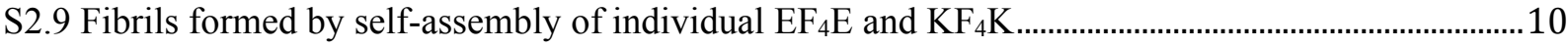

* Address correspondence to hcui6@jhu.edu. S1 


\section{S1 Molecular characterization of the studied peptides}

\section{S1.1 EFFFFE $\left(\mathrm{EF}_{4} \mathrm{E}\right)$}<smiles>CC(=O)NC(CCC(=O)O)C(=O)N[C@@H](Cc1ccccc1)C(=O)NC(Cc1ccccc1)C(=O)N[C@@H](Cc1ccccc1)C(=O)NC(Cc1ccccc1)C(=O)N[C@@H](CCC(=O)O)C(N)=O</smiles>

Scheme S1. Chemical structure of peptide $\mathbf{E F}_{\mathbf{4}} \mathbf{E}$ with expected molecular weight of 905.4.

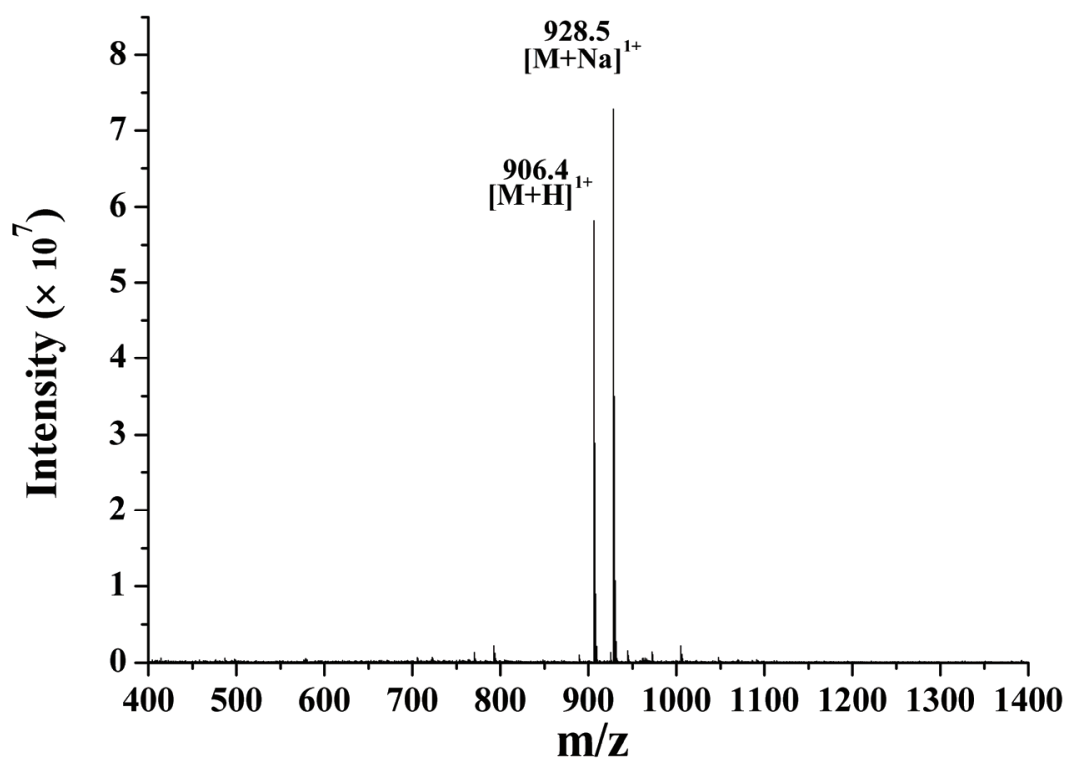

Figure S1a. Electrospray ionization mass spectrometry of $\mathbf{E F} 4 \mathbf{E}$.

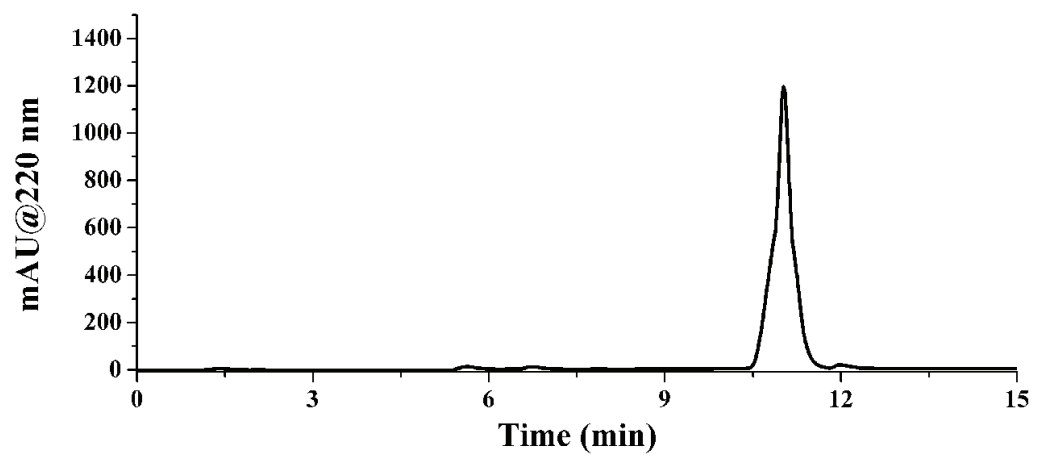

Figure S1b. Analytical reverse-phase HPLC of $\mathbf{E F}_{4} \mathbf{E}$.

* Address correspondence to hcui6@jhu.edu. 


\section{S1.2 KFFFFK $\left(\mathrm{KF}_{4} \mathrm{~K}\right)$}<smiles>CC(=O)NC(CCCCN)C(=O)N[C@@H](Cc1ccccc1)C(=O)NC(Cc1ccccc1)C(=O)N[C@@H](Cc1ccccc1)C(=O)NC(Cc1ccccc1)C(=O)N[C@@H](CCCCN)C(N)=O</smiles>

Scheme S2. Chemical structure of peptide $\mathbf{K F}_{4} \mathbf{K}$ with expected molecular weight of 903.5.

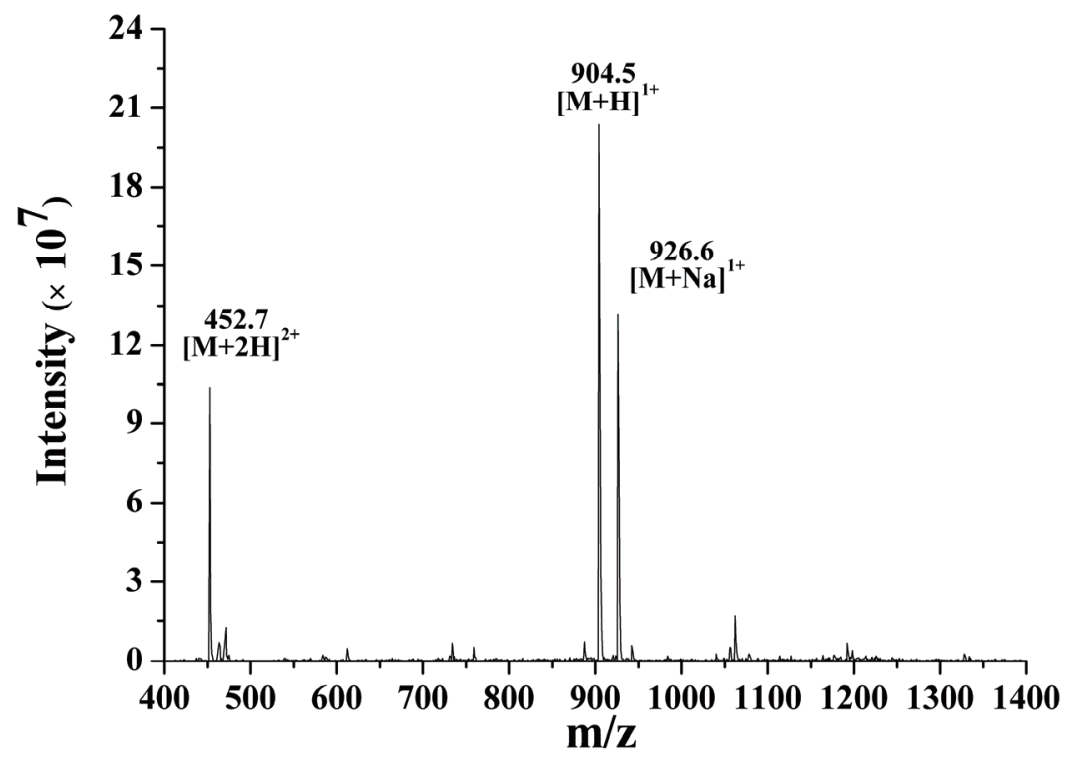

Figure S1c. Electrospray ionization mass spectrometry of $\mathrm{KF}_{4} \mathrm{~K}$.

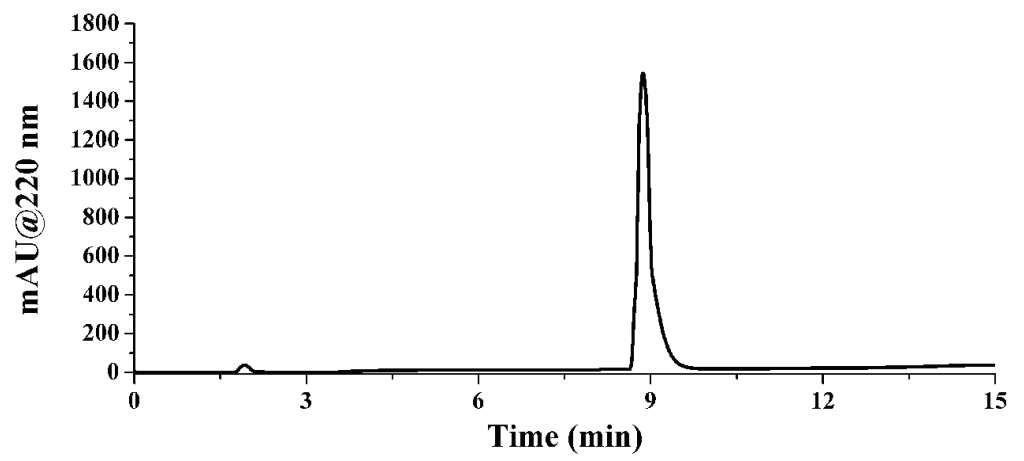

Figure S1d. Analytical reverse-phase HPLC of $\mathbf{K F}_{4} \mathbf{K}$. 


\section{$\operatorname{S1.3~EFFFFK~}\left(\mathrm{EF}_{4} \mathrm{~K}\right)$}<smiles>CC(=O)NC(CCC(=O)O)C(=O)N[C@@H](Cc1ccccc1)C(=O)NC(Cc1ccccc1)C(=O)N[C@@H](Cc1ccccc1)C(=O)NC(Cc1ccccc1)C(=O)N[C@@H](CCCCN)C(N)=O</smiles>

Scheme S3. Chemical structure of peptide $\mathbf{E F}_{4} \mathbf{K}$ with expected molecular weight of 904.5 .

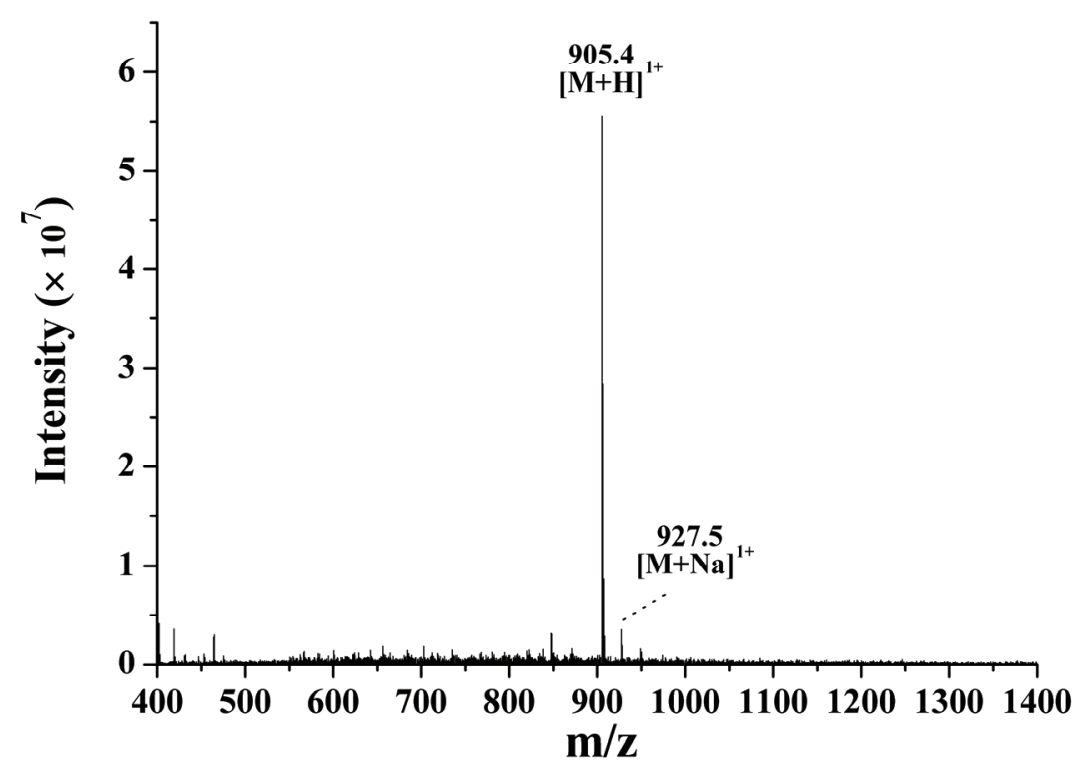

Figure S1e. Electrospray ionization mass spectrometry of $\mathbf{E F}_{4} \mathrm{~K}$.

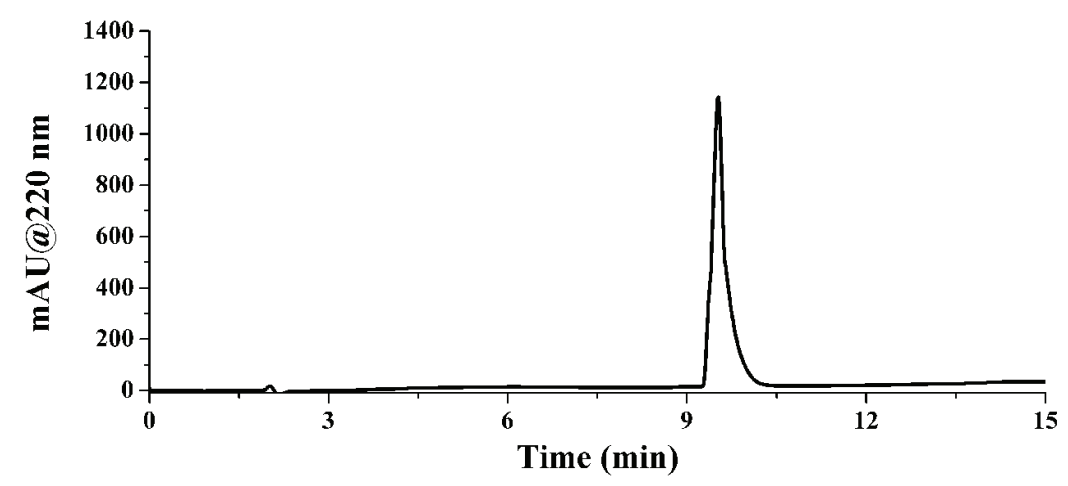

Figure S1f. Analytical reverse-phase HPLC of $\mathbf{E F}_{4} \mathbf{K}$.

* Address correspondence to hcui6@jhu.edu. 


\section{S1.4 EIIIIE (EI 4 E)}<smiles>CCC(C)[C@H](NC(=O)[C@H](NC(=O)[C@H](NC(=O)[C@H](NC(=O)[C@H](CCC(=O)O)NC(C)=O)C(C)CC)C(C)CC)C(C)CC)C(=O)N[C@@H](CCC(=O)O)C(N)=O</smiles>

Scheme S4. Chemical structure of control peptide molecule $\mathbf{E I}_{4} \mathbf{E}$ with expected molecular weight of 769.5.

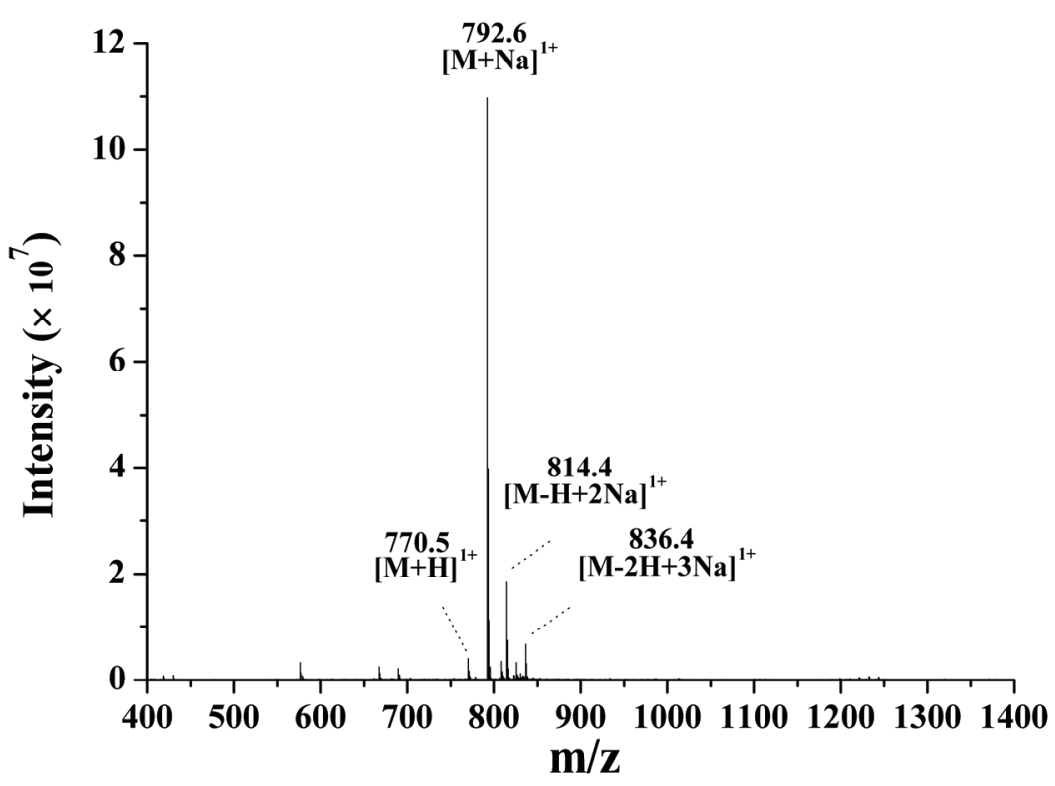

Figure S1g. Electrospray ionization mass spectrometry of $\mathbf{E I}_{4} \mathbf{E}$.

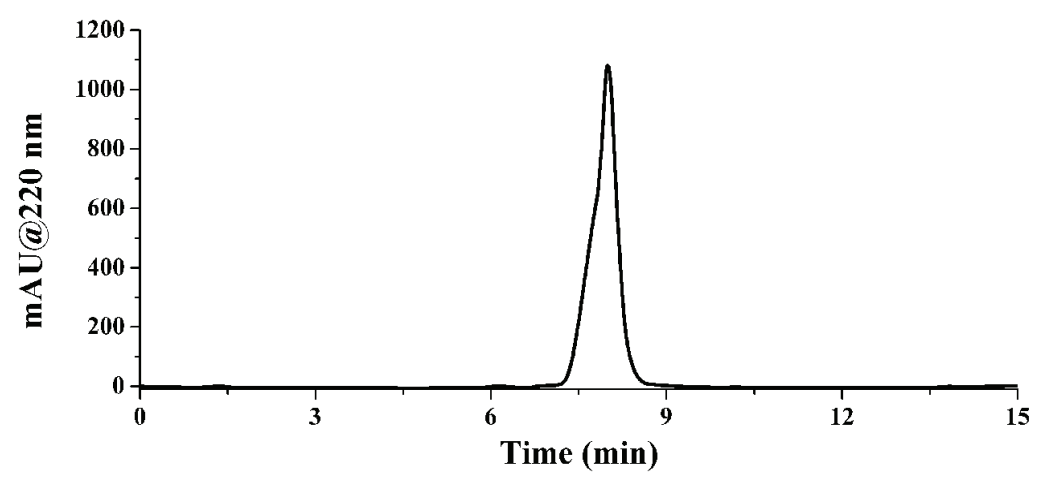

Figure S1h. Analytical reverse-phase HPLC of EI 4 E. 


\section{S2 Characterization of the self-assembled nanostructures}

\section{S2.1 Height measurement of $\mathrm{EF}_{4} \mathrm{E}$ twisted ribbons by $\mathrm{AFM}$}
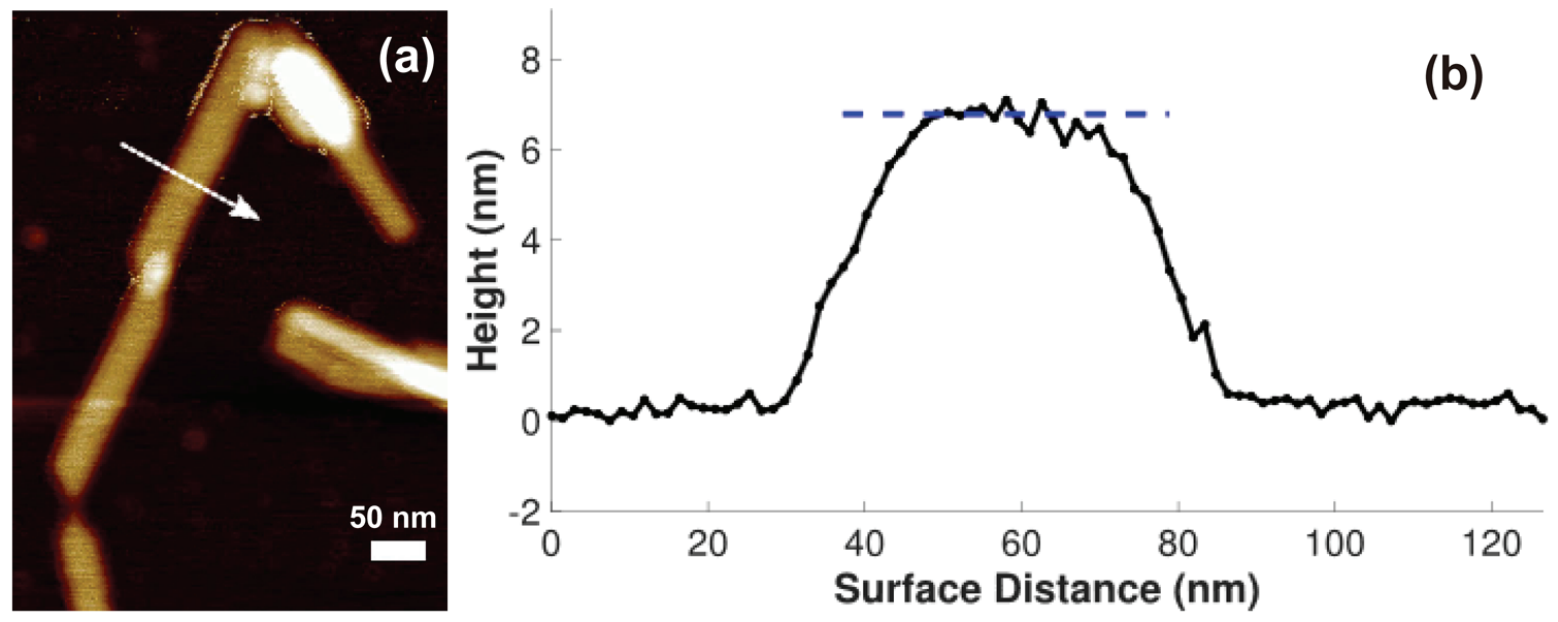

Figure S2. ( $a, b)$ Height measurement of the twisted ribbons using AFM.

\section{S2.2 TEM images of self-assembled nanostructures of $\mathrm{EF}_{4} \mathrm{E}$}

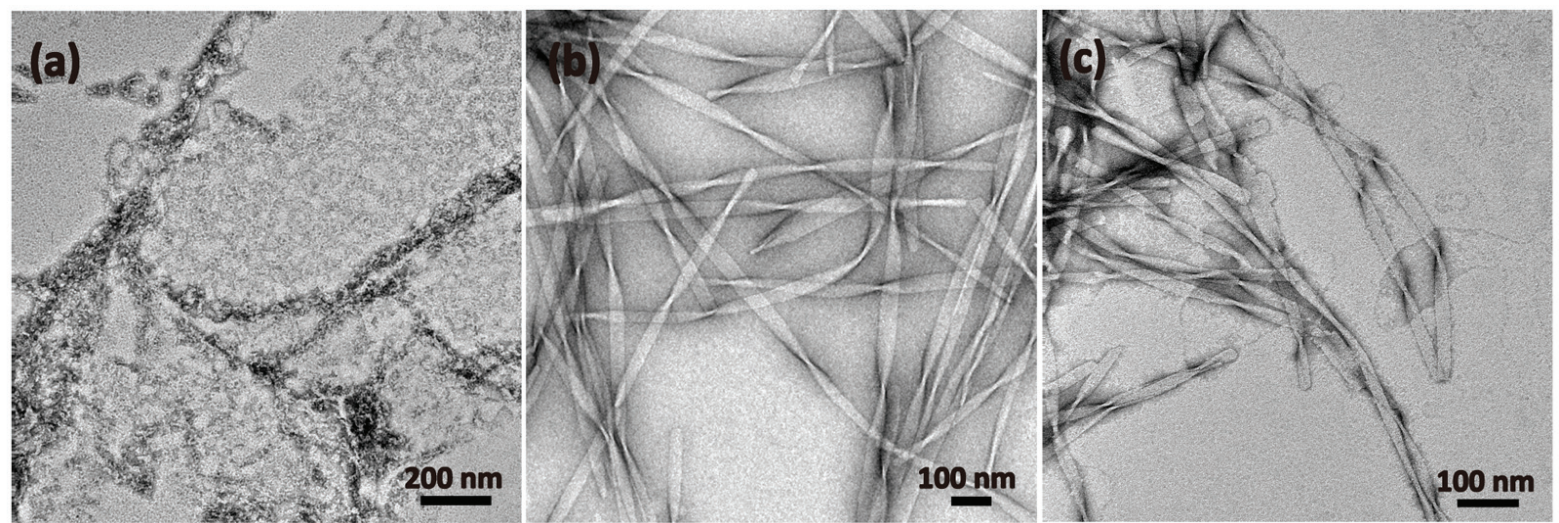

Figure S3. Representative TEM images of self-assembled nanostructure formed by peptide $\mathbf{E F} \mathbf{E}$ AT different $\mathrm{pH}$. The self-assembly process was carried out in water at a concentration of $100 \mu \mathrm{M}$ after $24 \mathrm{~h}$ aging. The $\mathrm{pH}$ of the initial solution was about 4.5. $1 \mathrm{M} \mathrm{HCl}$ or $\mathrm{NaOH}$ was used to adjust the $\mathrm{pH}$ to the desired range: (a) ill-defined structure was obtained at $\mathrm{pH} 7$; twisted ribbons were observed at (b) $\mathrm{pH} 4.5$ and (c) $\mathrm{pH} 3$. 


\section{S2.3 TEM images of self-assembled nanostructures of $\mathrm{KF}_{4} \mathrm{~K}$}

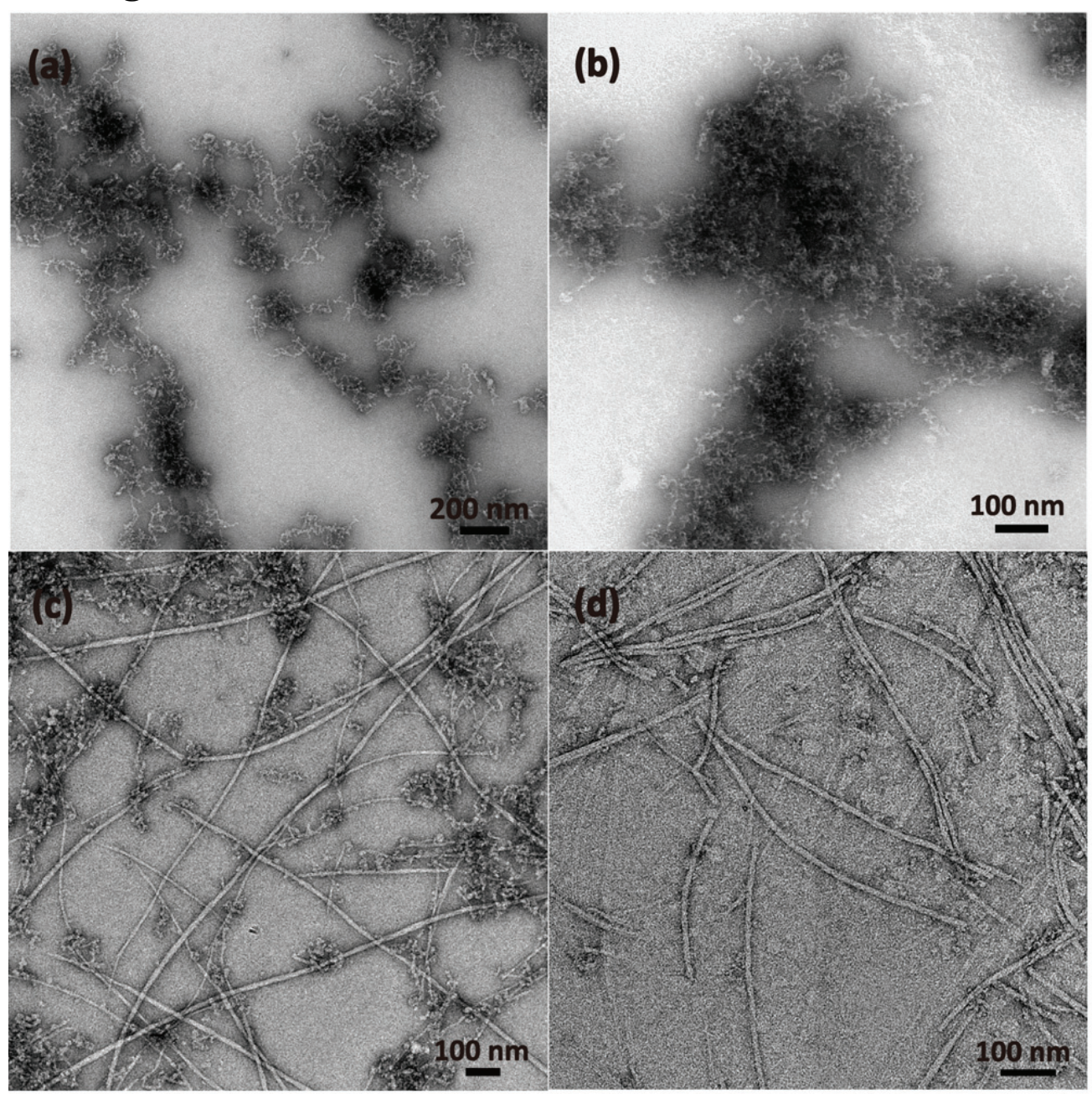

Figure S4. Representative TEM images of self-assembled nanostructures formed by peptide $\mathbf{K F}_{4} \mathbf{K}$. The selfassembly process was carried out in $0.1 \% \mathrm{NH}_{4} \mathrm{OH}$ solution at a concentration of $100 \mu \mathrm{M}$ (a) in room temperature after $24 \mathrm{~h}$ aging. Ill-defined structures were obtained (a). (b-d) The solution was heated in $80^{\circ} \mathrm{C}$ for $1 \mathrm{~h}$ before $24 \mathrm{~h}$ aging to promote the self-assembly process at different $\mathrm{pH}$. The $\mathrm{pH}$ of the $0.1 \% \mathrm{NH}_{4} \mathrm{OH}$ solution was about 10.5 , and $1 \mathrm{M} \mathrm{HCl}$ or $\mathrm{NaOH}$ was used to adjust the $\mathrm{pH}$ to the desired range. (b) Ill-defined structures were obtained at $\mathrm{pH}$ 7; (c) fibrils and some ill-defined structures were obtained in $\mathrm{pH} 10.5$; (d) fibrils were the dominant structure at $\mathrm{pH}$ 12 , but the precipitation was observed with time. 


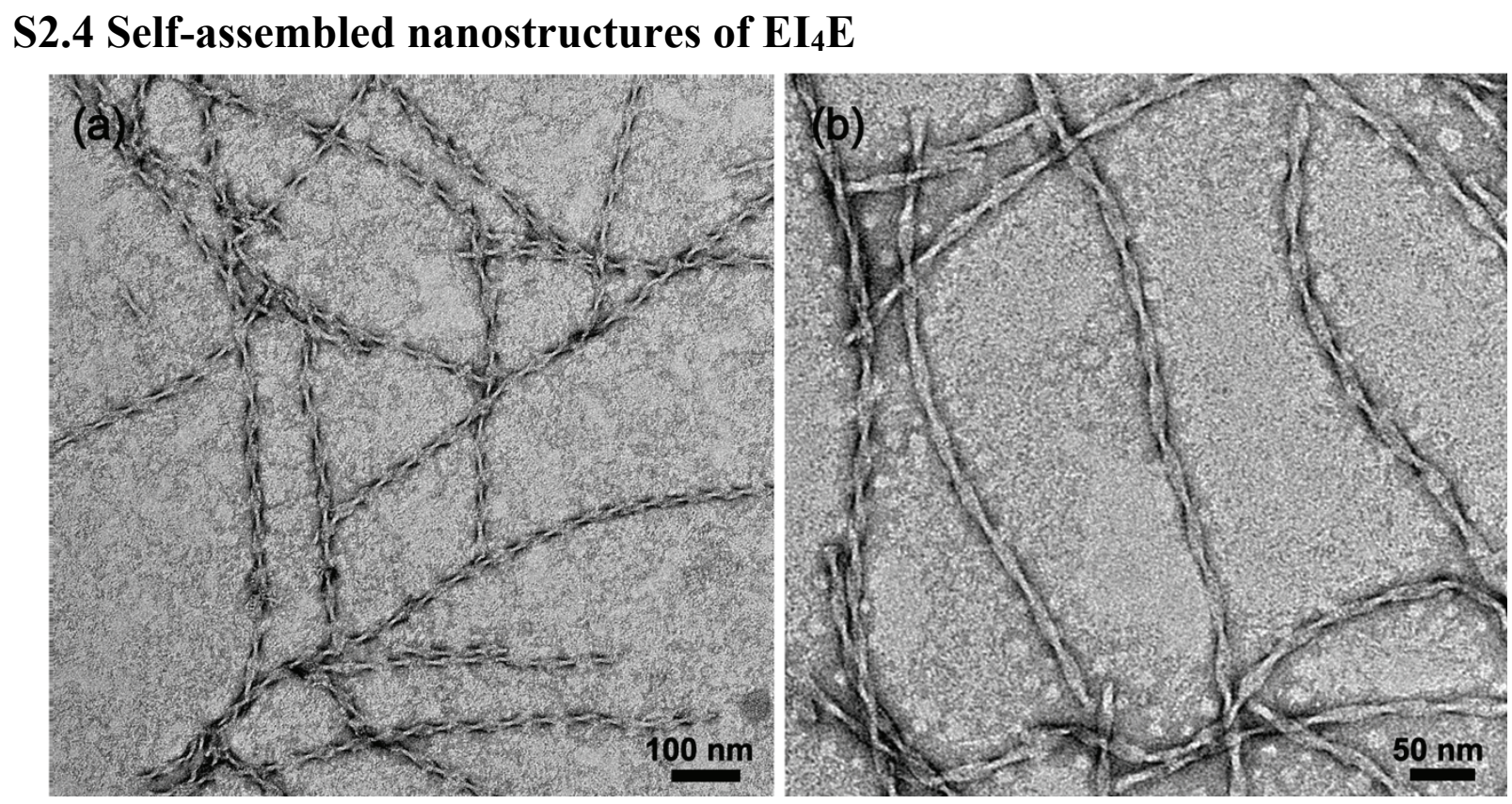

Figure S5. TEM images of twisted ribbons formed by self-assembly of $\mathbf{E I}_{4} \mathbf{E}$ in water, $100 \mu \mathrm{M}$ with $24 \mathrm{~h}$ aging. Narrow twist ribbons were obtained.

\section{S2.5 CD of $\mathbf{E I}_{4} \mathrm{E}$ nanostructure}

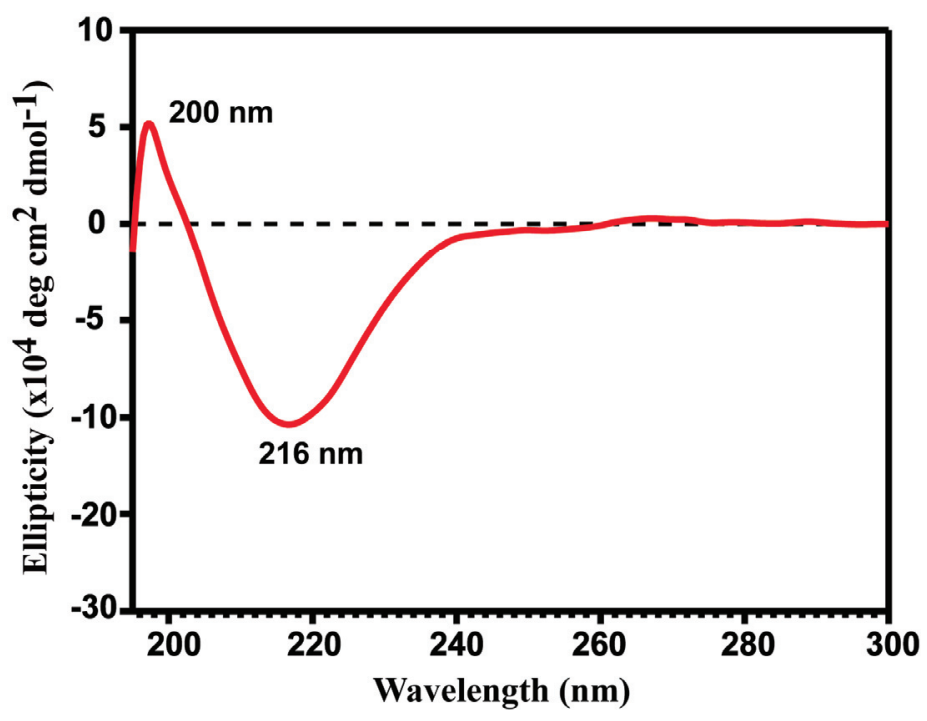

Figure S6. CD spectrum of the $\mathbf{E I}_{4} \mathbf{E}$ self-assembled nanostructure. 


\section{S2.6 Co-assembly of $\mathrm{EF}_{4} \mathrm{E}$ and $\mathrm{KF}_{4} \mathrm{~K}$ at different concentrations in water}
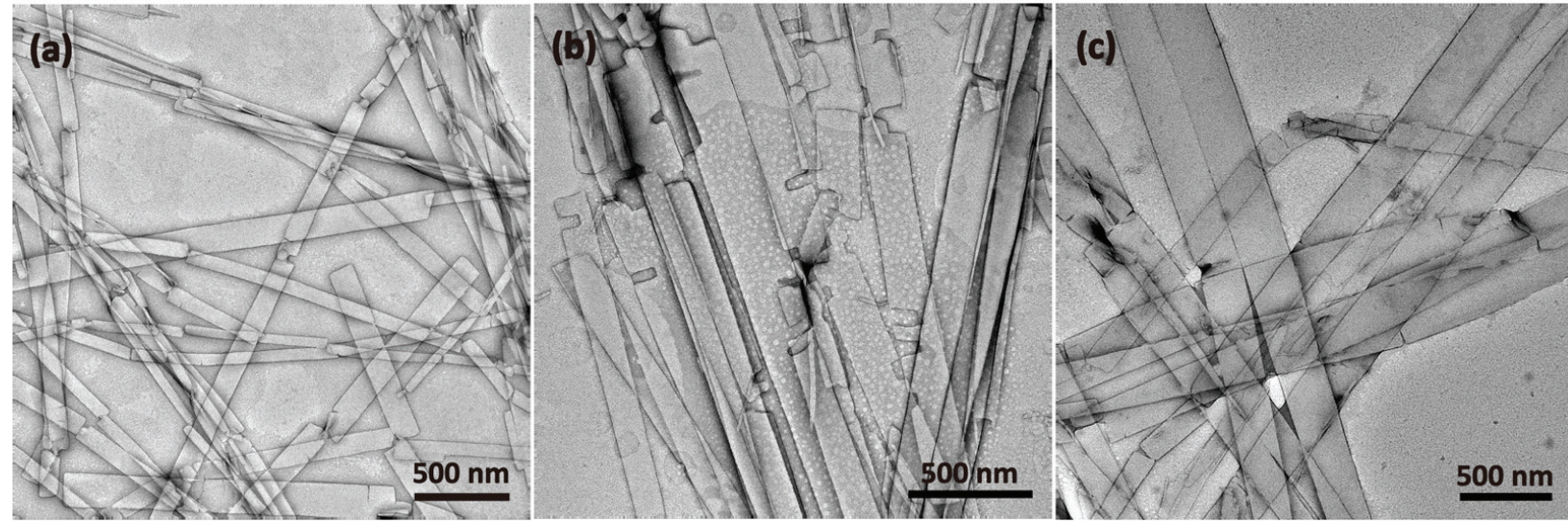

Figure S7. TEM images of self-assembled structure of $\mathbf{E F}_{4} \mathbf{E}$ and $\mathbf{K F}_{4} \mathbf{K}$ mixture in water, mixing molar ratio 2:1: (a) $100 \mu \mathrm{M}$, (b) $500 \mu \mathrm{M}$, (c) $1000 \mu \mathrm{M}$. The widths of the belts from (a) to (c) are approximately $110 \mathrm{~nm}, 180 \mathrm{~nm}$ and $240 \mathrm{~nm}$, respectively.

\section{S2.7 Morphological transformation of $\mathrm{EF}_{4} \mathrm{E}$ and $\mathrm{KF}_{4} \mathrm{~K}$ mixture}

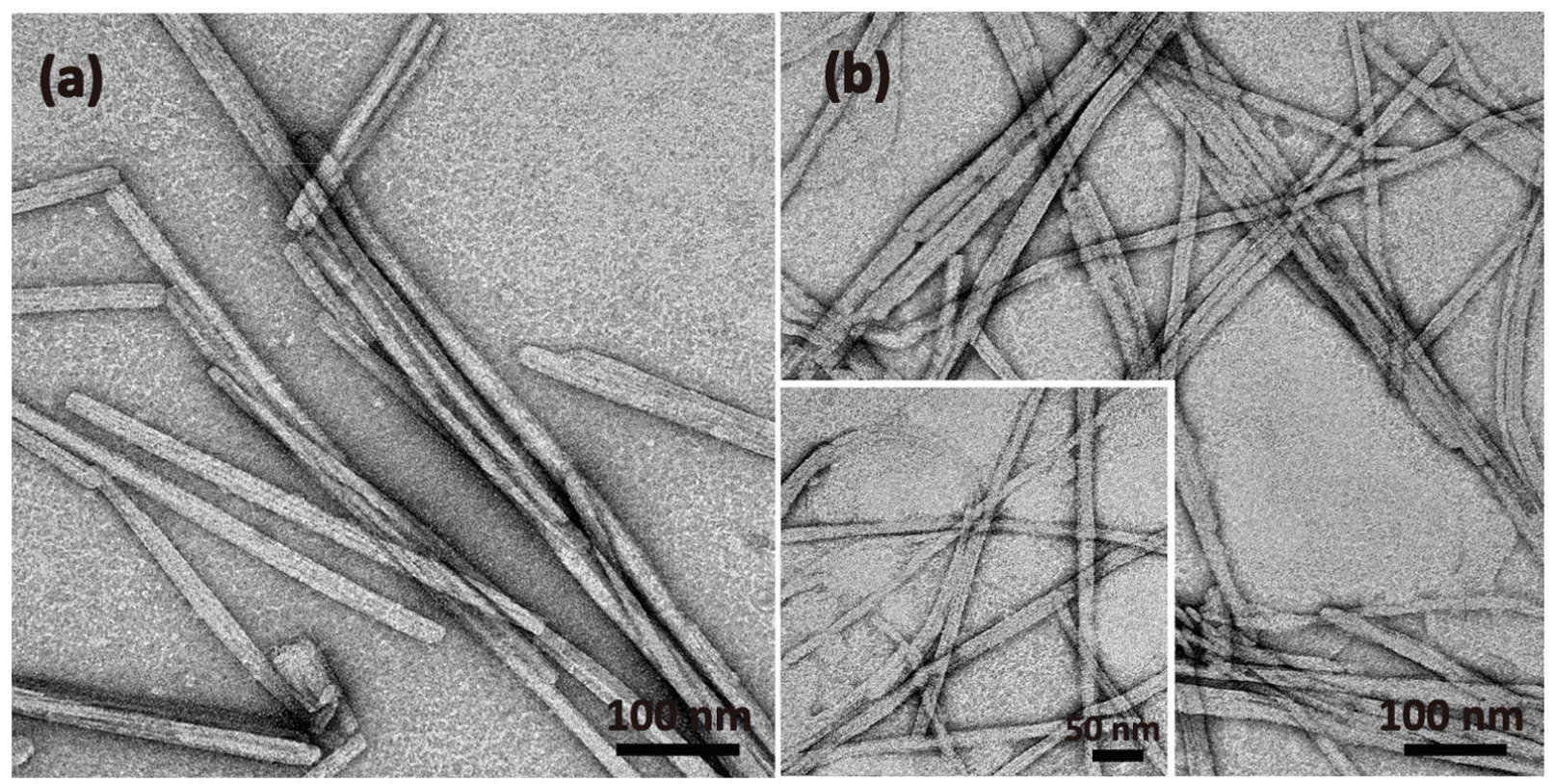

Figure S8. Morphological transformation of the $\mathbf{E F}_{4} \mathbf{E}$ and $\mathbf{K F}_{4} \mathbf{K}$ mixture (1:1) from in water to in $0.1 \% \mathrm{NH}_{4} \mathrm{OH}$ solution. By adding $1 \mathrm{M} \mathrm{NH}_{4} \mathrm{OH}$ into the solution illustrated in Figure $2 \mathrm{~b}$, the wide belts transformed into narrow belts (a) after overnight aging. (b) The wide belts directly dissociated into flexible grooved belts with dark channels when heated to $80^{\circ} \mathrm{C}$ for $1 \mathrm{~h}$ before overnight aging.

* Address correspondence to hcui6@jhu.edu. 


\section{S2.8 Height measurement of $\mathrm{EF}_{4} \mathrm{~K}$ belts by AFM}
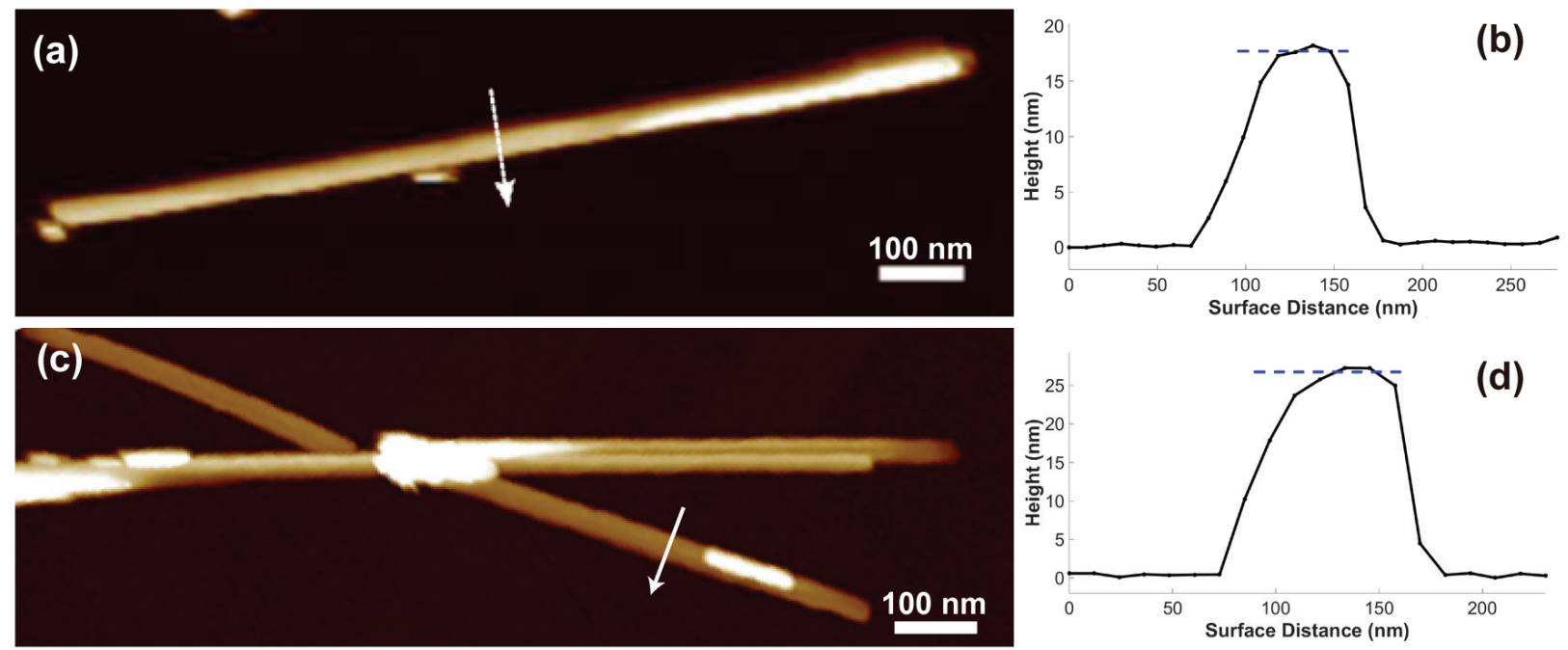

Figure S9. Height measurement of the belts formed by self-assembly of $\mathbf{E F}_{4} \mathbf{K}$ : (a) Self-assembled belts in water at the concentration of $100 \mu \mathrm{M}$, and the corresponding height measurement (b); (c) Self-assembled belts in $0.1 \%$ $\mathrm{NH}_{4} \mathrm{OH}$ solution at the concentration of $100 \mu \mathrm{M}$, and the corresponding height measurement (d).

\section{S2.9 Fibrils formed by self-assembly of individual $\mathrm{EF}_{4} \mathrm{E}$ and $\mathrm{KF}_{4} \mathrm{~K}$ EFFFFE KFFFFK}

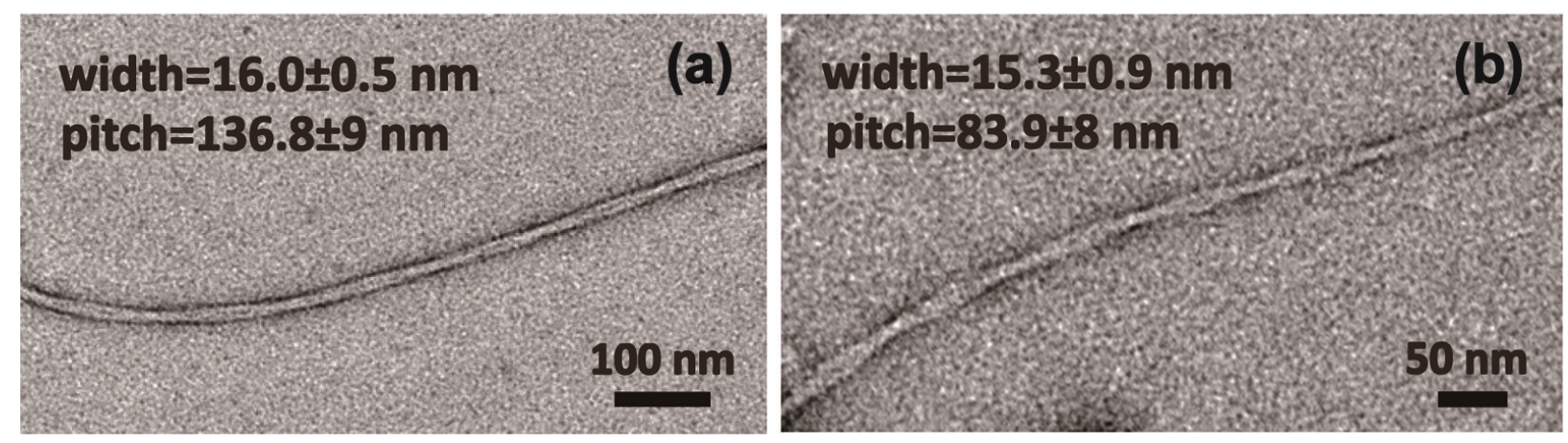

Figure S10. Fibrils formed by self-assembly of $\mathbf{E F}_{4} \mathbf{E}$ (a) and $\mathbf{K F}_{4} \mathbf{K}$ (b). Although the twisted ribbon was the dominant structure of $\mathbf{E F}_{4} \mathbf{E}$ in water, few fibrils could also be found. These two fibrils have nearly the same width but differ in pitch length. 